\title{
PENDIDIKAN KESEHATAN MENGGUNAKAN MEDIA VEGETABLE AN PUZZLE SEBAGAI UPAYA PENINGKATAN KEMAMPUAN PEMILIHAN KONSUMSI MAKANAN SAYUR PADA ANAK USIA PRA SEKOLAH
}

\author{
Health Education Using an Puzzle Vegetable Media as an Effort to Improve \\ Consumption Selection Abilities \\ Vegetable Food In Pre School Age
}

\author{
Pipit Festi Wiliyanarti ${ }^{1}$, Eko Chandra ${ }^{2}$ \\ ${ }_{1,2}$ Departemen Komunitas Fakultas Ilmu Kesehatan UM Surabaya
}

\begin{abstract}
ABSTRAK
Usia prasekolah (3-6 tahun) merupakan masa perkembangan intelektual dan emosional yang pesat bagi anak. Anak membutuhkan nutrisi yang cukup untuk mencapai tumbuh kembang yang optimal. Kebutuhan gizi merupakan kebutuhan yang sangat penting dalam membantu proses tumbuh kembang anak serta mencegah berbagai penyakit akibat gizi buruk pada tubuh. Pelaksanaan pengabdian ini menggunakan metode pendampingan dan pendidikan kesehatan pada kelompok anak pra sekolah dalam bentuk permainan kelompok di Surabaya. Media yang digunakan berupa puzzle sayuran. Hasil pengabdian setelah pendampingan dan permainan puzzle sayur anak rata-rata menunjukkan terdapat peningkatan pengetahuan pada anak tentang manfaat sayuran dan jenis sayuran, hasil pengetahuan baik sebanyak 20 anak $(80 \%)$ dari 25 responden, Kesimpulan, terjadi peningkatan pengetahuan anak tentang manfaat sayur dan jenis sayuran. Penggunaan alat bantu dan metode permainan puzzle sayur dapat digunakan sebagai media pembelajaran bagi anak dalam penyuluhan tentang kosumsi buah dan sayur.
\end{abstract}

Kata Kunci: makanan sayur, anak pra sekolah, media puzzle

\begin{abstract}
Preschool age (3-6 years) is a period of rapid intellectual and emotional development for children. Children need adequate nutrition to achieve optimal growth and development. Nutrition needs are very important needs in helping the process of growth and development of children and prevent various diseases due to malnutrition in the body. The implementation of this service uses the method of mentoring and health education to groups of pre-school children in the form of group games in the Surabaya area. The media used is a vegetable puzzle.The results of community service after mentoring and children's vegetable puzzle games showed an increase in children's knowledge about the benefits of vegetables and types of vegetables, the results of good knowledge were 20 children (80\%) of 25 respondents, children were enthusiastic about playing games.In conclusion, there are an increase in children's knowledge about the benefits of vegetables and types of vegetables. The use of tools and methods of vegetable puzzle games can be used as learning media for children in counseling about fruit and vegetable consumption.
\end{abstract}

Keywords: vegetable food, pre-school age, puzzle media

\section{PENDAHULUAN}

Kebutuhan nutrisi merupakan kebutuhan yang sangat penting dalam membantu proses pertumbuhan dan perkembangan anak serta mencegah terjadinya berbagai penyakit akibat kurang nutrisi dalam tubuh.

Zat gizi merupakan unsur yang penting bagi tubuh. Zat gizi tersebut diantaranya adalah karbohidrat, lemak, protein, vitamin, mineral dan air. Beberapa dari nutrisi yang sangat berguna tersebut terkandung didalam sayuran (Wiliyanarti, 2018). Anak cenderung tidak mau makan sayur, padahal intake protein, kalsium, zat besi, vitamin A dan D yang adekuat merupakan hal penting selama masa ini, maka harus diperhatikan oleh orang tua 
agar anak mendapatkan cukup nutrisi pada masa pertumbuhan, terlebih lagi asupan sayur-sayuran.

Hasil Riset Kesehatan Dasar 2018 menunjukkan bahwa tingkat konsumsi Hasil Riset Kesehatan Dasar 2018 menunjukkan bahwa tingkat konsumsi sayur dan buah penduduk Indonesia tahun 2018 sebesar 93,5\% turun dari tahun 2015 sebesar 93,6\%. Sedangkan tingkat konsumsi sayur di Jawa Timur adalah berada dibawah rerata konsumsi nasional, tepatnya berada diposisi 5 terbawah di angka $92 \%$ (Kementrian Kesehatan, 2019 ).

Menurut data survey konsumsi makanan individu Indonesia 2018 diketahui rata-rata konsumsi sayur dan olahannya pada penduduk Indonesia sebesar 45,8 gram per-orang per hari (Balitbangkes, 2018). Angka tersebut masih jauh dari anjuran konsumsi sayur di Indonesia yang seharusnya sebanyak 150-200 gram sayur per orang per hari. Rendahnya konsumsi tersebut menjadikannya masuk dalam 10 besar penyebab kematian di dunia (Kementrian Kesehatan RI, 2019).

Data BPOM tahun 2006-2010 menunjukkan $48 \%$ jajanan anak sekolah mengandung bahan kimia yang berbahaya. Hasil pengujian 10.429 sampel pangan jajanan anak sekolah (PJAS) dari seluruh Indonesia yang dilakukan BPOM pada tahun 2014, masih ada $23,82 \%$ sampel yang tidak memenuhi syarat. Penyebab PJAS tidak memenuhi syarat pada tahun 2014 adalah $74,9 \%$ disebabkan pencemaran mikroba, 15,7\% menggunakan Bahan Tambahan Pangan (BTP) berlebihan, dan $9 \%$ menggunakan bahan berbahaya. Atas dasar situasi tersebut, gerakan membawa bekal nasional dilaksanakan setiap tahunnya. Sedangkan kosumsi sayur Sayuran yang paling banyak dikonsumsi oleh penduduk Indonesia menurut Studi Diet Total tahun 2016 adalah sayuran daun dengan persentaser $79,1 \%$ (Kementrian Kesehatan RI, 2020).

Penelitian yang dilakukan Diah (2015) Rendahnya konsumsi sayur pada siswa disebabkan karena rasa sayur yang pahit cenderung kurang disukai siswa dan juga kurangnya pengenalan oleh orang tua secara dini tentang sayur membuat anak kurang menyukai sayur. Penelitian yang dilakukan di Bogor menghasilkan hasil dimana dari seluruh siswa TK Papandayan yang menjadi sampel penelitian terdapat $60 \%$ yang memiliki tingkat konsumsi sayur yang kurang. Hal ini disebabkan oleh uang saku siswa dan pengetahuan orang tua tentang sayur yang rendah sehingga membuat pengenalan konsumsi sayur pada anak menjadi lambat sehingga anak lebih cenderung menyukai makanan lain yang tidak sehat (Andika, 2015).

\section{METODE PELAKSANAAN}

$\begin{array}{clr}\text { Metode } & \begin{array}{l}\text { Pengabdian } \\ \text { digunakan }\end{array} & \begin{array}{r}\text { yang } \\ \text { adalah }\end{array}\end{array}$ pendampingan dan pendidikan kesehatan pada TK di wilayah Kalijudan. Tahapan pengabdian meliputi tahap pertama melakukan analisis situasi, tahap kedua melakukan perencanaan penyelesaian masalah bersama guru dan orangtua siswa pra sekolah, tahap ke tiga adalah melakukan pendidikan kesehatan dan melakukan pendampingan pada orang tua dan siswa. Tahap ke empat melakukan evaluasi pengabdian. Tujuan pengabdian ini adalah meningkatkan kemampuan anak dalam memilih makanan sayur dan buah sebelum dan sesudah diberikan vegetable puzzle. Pelaksanaan pengabdian diawali dengan memberikan kuesioner tentang 
kemampuan anak dalam memilih makanan dengan bantuan enumerator. Jumlah kuesioner 10 item tentang makanan sehari-hari untuk anak. Selanjutnya anak di berikan vegetable puzzele yaitu gambar makanan sayur. Adapun cara melakukan permainan adalah anak memilih makanan yang terbuat dari sayur diikuti dengan kegunaanya. Tahapan permainan di lakukan 3 sesi pengulangan dengan waktu 10 menit. Setelah bermain selanjutnya anak diberikan kuesioner kembali dengan bantuan guru. Selanjutnya selama 2 minggu dilakukan observasi pemilihan makan dirumah dengan menggunakan lembar observasi pemilihan makanan pada anak.

\section{HASIL}

Kemampuan anak memilih makanan sayur sebelum dan sesudah dilakukan permainan menggunakan vegetable puzzle.

Tabel 1. Kemampuan memilih sayuran sebelum dilakuan penyuluhan dan permainan menggunakan vegetable puzzle pada anak pra sekolah di wilayah Kalijudan Surabaya.

\begin{tabular}{llclc}
\hline \multirow{2}{*}{$\begin{array}{l}\text { Kemampuan } \\
\text { memilih } \\
\text { sayuran }\end{array}$} & \multicolumn{2}{l}{$\begin{array}{l}\text { Sebelum } \\
\text { penyuluhan }\end{array}$} & \multicolumn{2}{l}{$\begin{array}{l}\text { Sesudah } \\
\text { penyuluhan }\end{array}$} \\
\cline { 2 - 5 } & $\mathrm{N}$ & $\%$ & $\mathrm{~N}$ & $\%$ \\
\hline Baik & 3 & 12 & 19 & 76 \\
Cukup & 5 & 20 & 4 & 16 \\
Kurang & 17 & 68 & 2 & 8 \\
\hline Total & 25 & 100 & 25 & 100 \\
\hline
\end{tabular}

Berdasarkan tabel diatas menunjukkan bahwa hasil konsumsi sayuran pada anak pra sekolah setelah diberikan permaianan vegetable puzzle terhadap kemampuan konsumsi sayur dari 25 anak pra-sekolah sebelum dilakukan permainan sebagian besar kurang 68\% yaitu sebanyak 17 anak, setelah melakukan permainan dan pemberian pendidikan kesehatan sebagain besar baik 19 anak (76\%).

Tabel 2. Hasil observasi dalam pemilihan kosumsi makanan sayur pada anak pra sekolah di wilayah kalijudan Surabaya

\begin{tabular}{lll}
\hline $\begin{array}{l}\text { Olahan Sayur } \\
\text { yang dipilih }\end{array}$ & Frekwensi & $\%$ \\
\hline Bayam & 6 & 24 \\
Jagung & 7 & 28 \\
Wortel & 9 & 36 \\
Sawi putih & 2 & 8 \\
Sawi hijau & 3 & 12 \\
Lain-lain (lobak, & 0 & 0 \\
markisa, tauge) & & 100 \\
\hline Total & 25 & .
\end{tabular}

Berdasarkan tabel menunjukkan bahwa hasil pemilihan olahan sayuran pada anak pra sekolah setelah diberikan permaianan vegetable puzzle terhadap kemampuan konsumsi sayur pada anak sebagian besar memilih olahan wortel $36 \%$, olahan jagung $28 \%$, dan olahan bayam $24 \%$.

Hasil pengabdian yang di lakukan pada anak usia pra-sekolah sebagian besar anak mengikuti aturan permainan vegetable puzzle, anak antusias dalam mengikuti permainan dan anak tidak mengalami kendala selama proses permainan sedangkan kategori kurang anak tidak menyelesaikan permainan sampai akhir karena bosan mengikuti permainannya. Semua orang tua anak sangat kooperatif dalam kegiatan permainan vegetable puzzle. Berdasarkan hasil pengabdian bahwa media puzzle sayuran dapat meningkatkan tingkat pengetahuan memilih konsumsi sayuran pada anak usia prasekolah. 


\section{PEMBAHASAN}

Pelaksanaan pengabdian yang dilakukan selama 2 minggu menggunakan 4 tahapan menunjukkan hasil bahwa sebagaian besar anak pra sekolah mempunyai kempuan memilih makan sayur yang kurang yaitu 68\%. Berdasarkan hasil wawancara dengan orang tua sebanyak $45 \%$ orang tua menyatakan anak anak lebih menyukai makanan tanpa sayur seperti ayam goreng dan olahan ayam misalnya nugget. Pemberian permainan vegetable puzzle yang diterapkan pada pengabdian diharapkan dapat mengenalkan makan sayur dan manfaatnya, sehingga anak bisa tertarik untuk mengkosumsi sayuran karena mengetahui manfaatnya ( Farida \& Ida, 2010).

Media puzzle adalah media yang menarik dan menyenangkan akan meningkatkan kognitif anak. Guru pendamping dapat menggunakan cara ini sebagai media pembelajaran yang menarik,sederhana dan tidak rumit dan memiliki warna yang menarik ( Mahardika, et al, (2013); Ni, Q., \& Yu, Y. (2015).

Hal ini sejalan dengan hasil penelitian hasil penelitian yang dilakukan Diah (2015) di bahwa vegetable puzzle dapat mempengaruhi tingkat konsumsi sayur pada anak usia pra sekolah. Sayuran merupakan zat gisi yang sangat dibutuhkan tubuh, zat ini memiliki komponen serat yang membantu metabolism pencernan makanan (Haryani, 2011; Wiliyanarti, 2018). Pengolahan sayuran dan buah sesuai dengan kecukupan gizi pada anak sekolah sangat menjadi perhatian. Kekurangan kecukupan vitamain pada anak dapat berdampak pada kesehatan fisik (Krolner et al, 2011; Supariasa, 2011). Respon anak saat dilakukan pendidikan kesehatan dengan melakukan permainan sangat antusias, Pendidikan kesehatan dengan menggunakan media permainan dapat meningkatkan pengetahuan yang medah diterima oleh anak-anak usia pra sekolah. Sedangkan dalam pelaksaan pengabdian ada beberapa anak mengalami kesulitan dalam melakukan permainan hal ini disebabkan karena karakteristik anak yang berbeda baik usia, perkembanagan dan latar belakang pola asuh dalam keluarga serta lingkungan pada anak.

Media vegetable puzzle merupakan metode yang sesuai dengan perkembangan kognitif dan afektif anak usia pra sekolah. Saat pemainan dengan media vegetable puzzle berlangsung merupakan proses yang penting, terjadi penyerapan pengetahuan yang disampaikan instruktur dan juga dari puzzle yang dimainkan kepada audience. Proses inilah yang menjadi pengalaman seorang anak dan menjadi tugas instruktur permainan untuk menampilkan kesan menyenangkan pada saat membimbing audience dalam memainkan game (Demitri, 2015; Muazzomi, 2017.

Berdasarkan hal tersebut vegetable puzzle dapat meningkatkan tingkat konsumsi sayur pada anak usia pra-sekolah dikarenakan anak akan mengadopsi pengetahuan yang didapat dari permainan vegetable puzzle yang berisi tentang pesan-pesan baik, senang makan sayur, tidak rewel dan memilihmilih jenis makanan saat waktu makan tiba, selanjutnya anak diharapkan dapat menerapkan pesan-pesan yang disampaikan pada kehidupan sehari-hari.

Peran orang tua sangat penting dalam mengembangkan budaya untuk makan sayur. Penyediaan olahan 
makanan dirumah menjadi factor keberhasilan agar anak menyukai makan sayur. Selain itu peran guru pendamping dapat menjadikan sumber informasi bagi anak. Kebiasaan yang baik pada anak yang dimulai dari dini akan meningkatkan perilaku makan sehat pada anak.

\section{KESIMPULAN}

Pemberian pendampingan dan pendidikan kesehatan tentang pemilihan sayur pada anak dapat meningkatkan pengetahuan anak. Keluarga berperan penting dalam perilaku pemilihan makan sehari hari.

\section{DAFTAR PUSTAKA}

Andika Mohammad dk., 2015. Konsumsi Makanan Sayur Anak Usia Sekolah Dasar di Bogor. Departemen Gizi Masyarakat. Fakultas Ekologi Manusia (FEMA), Institut Pertanian Bogor.

Badan Penelitian dan Pengembangan Kesehatan (Balitbangkes), 2018. Infodatin. Kebutuhan gisi pada usia anak. Jakarta. Kementrian Kesehatan RI

Demitri., 2015. Pengaruh pendidikan Gizi Tentang Pola Makan Seimbang Melalui Game Puzzle dan Gambar Animasi Terhadap Peningkatan Pengetahuan Anak

Diah Kartika N, Ronny Aruben dkk., 2015. Faktor-Faktor Yang Mempengaruhi Konsumsi Makanan Buah dan Sayur Pada Anak Pra sekolah Paud TK Sapta Prasetya Kota Semarang. Jurnal Kesehatan Masyarakat Vol 3, No 1, Januari 2015.

Farida, Ida., 2010. Faktor-Faktor Yang Berhubungan Dengan Perilaku Konsumsi Buah di Kota Bekasi.
Skripsi Universitas Islam Negri Syari Hidayatullah : Jakarta.

Haryani., 2011. Gizi Untuk Kesehatan Ibu dan Anak. Graha Ilmu : Yogyakarta.

Kemenkes RI., 2013. Pedoman Gizi Seimbang. Diakses dari http://gizi.

Depkes.Go.id/download/pedoma n\%20gizi/PGS\%20ok.pdf.

Kementerian Kesehatan RI., 2015. Situasi Pangan Jajanan Anak Sekolah. Jakarta: Kementerian Kesehatan RI.

Kementerian Kesehatan RI. 2019. Laporan Nasional Riskesdas 2018. Jakarta: Lembaga Penerbitan Badan

Krolner, R, Rsamussen, M, Brug dkk (2011). Determinants Fruit and Vegetable Consumption Among Children and Adolescents : A Review of The Literature International Journal of Behavioral Nutrition and Physical Activity.

Nursalam.,2017. "Konsep dan Penerapan Metodelogi Penelitian Ilmu Keperawatan". Salemba Medika: Jakarta.

Ni, Q., \& Yu, Y. (2015). Research on educational mobile games and the effect it has on the cognitive development of preschool children. Zhejiang University of Technology

Mahardika, M Asrori, Yuniarni D, 2013. Permainan Edukatif dengan Media Puzzle mengembangkan Kemampuan Kognitif Anak Usia 4-5 tahunTK Islamiyah. Jurnal Pendidikan dan Pembelajaran Khatulistiwa. Vol.2 No.10. Universitas Tanjung Pura. 
Muazzomi, N. (2017). "Pengembangan

Alat Permainan Edukatif

Pendidikan Anak Usia Dini melalui Aplikasi Microsoft Powerpoint". Jurnal Ilmiah Universitas Batanghari Jambi.

Patmonodewo., 2010. Permainan Edukatif. PT Gramedia Pustaka Utama.

Purwantoko, R A.,2010.” Keefektifan Pembelajaran dengan Menggunakan Media Puzzle Terhadap Pemahaman IPA Siswa $S M P$ “. Jurnal Pendidikan Fisika Indonesia 6 hal. 123 - 127.
Pratitasari D., 2010. Makan Sayur Seasyik Bermain. Yogyakarta : B-First.

Suparisa, I D N dkk.,2011. Penilaian Status Gizi. Jakarta, EGC.

WHO.,2014. Kesehatan Gizi Anak Usia Pra-Sekolah. crom : www.who.com

Wiliyanarti, PF. 2018. Ilmu Gizi. Surabaya: UMSurabaya press 